Available online on 15.07.2021 at http://ujpr.org
Universal Journal of Pharmaceutical Research
An International Peer Reviewed Journal
Open access to Pharmaceutical research is an open access article distributed under the terms of the Creative Commons Attribution-Non
Commercial Share Alike 4.0 License which permits unrestricted non commercial use,
provided the original work is properly cited
Volume 6, Issue 3, 2021

\title{
PREVALENCE OF DIFFERENT HEPATITIS B VIRUS GENOTYPES AND RISK FACTORS ASSOCIATED AMONG SELECTED YEMENI PATIENTS WITH CHRONIC HEPATITIS B INFECTION
}

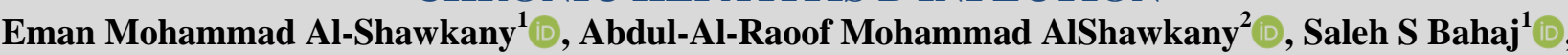
Arwa Mohammed Othman ${ }^{1}{ }^{1}$, Hassan A Al-Shamahy ${ }^{1}{ }^{\mathbb{D}}$, Azhar Azher Mohammed Al-Ankoshy ${ }^{3}$

${ }^{I}$ Medical Microbiology and Clinical Immunology Department, Faculty of Medicine and Health Sciences, Sana' a University.

${ }^{2}$ Molecular Genetics Department, College of Veterinary Medicine, Sana`a University, Yemen.

${ }^{3}$ Departement of physiology, Jabir Ibn Hayyan Medical University, Faculty of Medicine/Iraq.

\section{ABSTRACT}

Background and aims: Hepatitis B virus infection is a significant public health crisis global. Hepatitis B virus genotyping is an important tool in epidemiological studies to determine the category and extent of treatment and to predict the outcome of chronic infections, for instance hepatocellular carcinoma and cirrhosis. The study designed to determine the prevalence of hepatitis B virus genotypes among Yemeni patients with chronic hepatitis B (CHB) and to evaluate some of the associated risk factors.

Methods: Fifty patients (38 males, 12 females) with chronic hepatitis B from Al-Thawra Modern General Hospital, Al-Kuwait University Hospital, and AL-Gomhoria Hospital were included. HBV DNA was first detected by conventional PCR then HBV genotypes were determined using nested and multiplex PCR.

Results: Mixed HBV genotypes $(\mathrm{A}+\mathrm{B}+\mathrm{C}+\mathrm{D}+\mathrm{E}),(\mathrm{A}+\mathrm{B}+\mathrm{C}+\mathrm{D}+\mathrm{E}+\mathrm{F})$, and $(\mathrm{A}+\mathrm{B}+\mathrm{C}+\mathrm{D})$ were found to be the most prevalent $(60$ $\%)$, it is followed by genotype D (16\%), genotype B $(16 \%)$ and genotype A $(8 \%)$, whereas $\mathrm{C}, \mathrm{E}$, and $\mathrm{F}$ genotype were not found individually among the study population. Blood transfusion was associated with mixed infection $(\chi 2=13.06 ; p=0.005)$.

Conclusions: In assumption, this study demonstrates the general prevalence of hepatitis B virus genotypes among HBV-infected Yemeni hepatitis B patients who request medical consideration in a hospital. In mono-genotype HBV infection, genotype B and D were the most prevalent genotypes. In HBV mixed genotype infection, the $\mathrm{A} / \mathrm{B} / \mathrm{C} / \mathrm{D} / \mathrm{E}$ genotype was the most prevalent in the study area. In the future, based on genotype, clinical trials and treatment regimens must be individually assumed to efficiently manage chronic HBV infection. To this end, a prospective nationwide population study of HBV genotype spreading and clinical outcomes is suggested.

Keywords: chronic hepatitis B, HBV genotype, nested-PCR, prevalence, Yemen.

Article Info: Received 25 April 2021; Revised 23 May; Accepted 30 June, Available online 15 July 2021

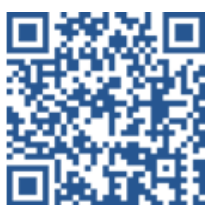

Cite this article-

Al-Shawkany EM, AlShawkany AM, Bahaj SS, Othman AM, Al-Shamahy HA, Al-Ankoshy AM. Prevalence of different Hepatitis B virus genotypes and risk factors associated among selected Yemeni patients with chronic Hepatitis B infection. Universal Journal of Pharmaceutical Research 2021; 6(3):24-29.

DOI: https://doi.org/10.22270/ujpr.v6i3.603

Address for Correspondence

Prof. Hassan A. Al-Shamahy, Faculty of Medicine and Heath Sciences, Sana'a University, P.O. Box 775 Sana'a, Yemen., Tel+967-770299847; E-mail: shmahe@yemen.net.ye

\section{INTRODUCTION}

One of the global public health problem is Hepatitis B virus (HBV) infection. $\mathrm{HBV}$ is belongs to the Hepadnaviridae family with a partially double-stranded DNA $^{1}$. It has been expected that about two billion people global have a proof of past or present infection with HBV and more than 358 million people have chronic lifelong infection and about 887000 people die every year due to the outcomes of hepatitis $\mathrm{B}^{2,3}$. The endemicity of hepatitis B virus was expected in Yemen, where the prevalence of positive HBsAg in the general population and $\mathrm{HCW}$ ranged from $8 \%$ to $20 \%$, among infants, it was $4.1 \%$, and up to $50 \%$ of health workers and populations usually had prior serological evidence of Hepatitis B virus infection in old reports. On the other hand, recent studies indicated that the rate of HBsAg, which ranges from $0.7-2 \%$ among the general population and to $4 \%$ among risk groups such as HCWs, as well as HBV decreased more among children $^{4-11}$. Though HBV contains DNA genome, it replicates via an RNA intermediate and due to lacking of proofreading activity for spontaneous error of viral reverse transcriptase, nucleotide mutations of $\mathrm{HBV}$ 
genome lead to the occurrence of various genotypes and subtypes ${ }^{4}$. Currently, ten HBV genotypes (A-J) and twenty-four sub-genotypes (A1-A3, B1-B5, C1-C6, D1-D6 and F1-F4) are reported ${ }^{13}$. HBV genotypes show a distinct geographic and ethnic distribution. Genotype $\mathrm{A}$ is the most commonly distributed genotype in Europe, USA, Canada, Brazil, India, Central African countries, Tunisia and Benin ${ }^{14-16}$. Genotype B is predominant in Taiwan, Philippines, Japan, Hong Kong, China, Thailand, Indonesia, Vietnam, and USA ${ }^{15-18}$. Genotype $\mathrm{C}$ is prevalent in Australia, Melanesia, Micronesia, Polynesia, Indonesia, China, Hong Kong, Korea, Taiwan, Vietnam, Thailand, Japan, India, Solomon Islands, Brazil and USA. Genotype D is widespread in Mediterranean region, Spain, Czech Republic, Russia, Turkey, Albania, Afghanistan, South Asia, Middle East, Tunisia, Iran, Solomon Islands, Polynesia, Melanesia, Micronesia, Brazil and USA ${ }^{18-20}$. Genotype $\mathrm{E}$ is found endemically in Western Africa while genotype $\mathrm{F}$ is widely distributed in new world countries. Genotypes G has been reported from France, and Germany and North America. Genotype $\mathrm{H}$ is recorded from Central America, South America and Mexico while Genotype I was isolated in Vietnam and Laos ${ }^{21-23}$.

Different HBV genotypes are also related with dissimilar clinical phenotypes and prognosis. The rate of chronicity following acute genotypes A and D infection were reported to be high compared with genotypes $\mathrm{B}$ and $\mathrm{C}^{\mathbf{1}, \mathbf{1 4 - 2 6}}$. Genotype $\mathrm{C}$ infection alone has been found to be associated with a significantly higher risk of cirrhosis and hepatocellular carcinoma than genotype B infection ${ }^{27,}{ }^{28}$. In contrast, Genotype B infection has a slower progression to liver cirrhosis than genotype $\mathrm{C}^{29}$. In addition, the response to antiviral therapy, mainly to interferon, is related to $\mathrm{HBV}$ genotypes. Patients with genotype $\mathrm{A}$ have been reported to be more sensitive for treatment by interferon $\alpha$ as compared to those infected with genotype $\mathrm{D}^{30}$. HBV genotype $\mathrm{B}$ develops antiviral resistance more than genotype $C^{31}$. This study aimed to determine the prevalence of different genotypes of hepatitis B virus among selected Yemeni patients with chronic hepatitis B (CHB) and to study the associated risk factors of contracting $\mathrm{HBV}$ infection.

\section{SUBJECTS AND METHODS}

\section{Study population}

Fifty patients with CHB were enrolled in this crosssectional study. According to a random sampling descriptive study, the design and group effect was left equal to one, and the $\mathrm{CHB}$ population size equaled 5640 patients who were admitted to the main hospitals in Sana'a city ${ }^{32,33}$. Since the expected frequency of genotype A or D is $20 \%$, and an acceptable margin of error for the prevalence of different HBV genotypes is $11 \%$ according to previous studies in region ${ }^{1,14-26}$; With a confidence level of $95 \%$ we need at least 50 randomly selected samples. The sample size was calculated using Epi Info version 6 (CDC). Patients from Al-Thawra General Modern Hospital, Kuwait University Hospital and Al-Jumhouri Hospital in
Sana'a-Yemen from December 2016 to June 2017 were selected from the diagnostic patient lists by systematic random selection (all 10 in the list are from the hospital records).

Inclusion criteria: Both males and Females infected with HBV for more than six months. Their HBs Ag test was positive but their $\mathrm{HBc} \operatorname{IgM}$ test was negative.

Exclusion patients: Excluded patients were acute hepatitis B (Anti-HBc IgM test was positive), have mixed infected with $\mathrm{HBV}$ and $\mathrm{HCV}$, any patient treated with antiviral of $\mathrm{HBV}$, and patients who had liver cirrhosis or hepatocellular carcinoma.

\section{Risks assessment}

Demographic data were collected at the time of sample collection using a predesigned questionnaire. Also questionnaire included risk factors determinants of HBV infections. Then all statistical analyzes of the data were performed using the Statistical Package for Social Sciences (SPSS) version 24 and Excel 2007. Quantitative data were presented as means and stander divisions whereas nominal data was presented as numbers and percentages. Chi-square test was used for verifying existence of associations. $P$ values $\leq 0.05$ were considered statistically significant.

\section{Ethical approval}

Ethical approval was obtained from the Medical Research and Ethics Committee of the College of Medicine and Health Sciences, Sana'a University with reference number (11) on 14/08/2015. All data, including patient identification, was also kept confidential. A brief explanation of the purpose and importance of the study was given to each participant in order to obtain verbal consent and obtain signature to prevent misunderstanding.

Specimens' collection: Five $\mathrm{ml}$ venous blood were collected from each patient by the first author. Laboratory work was carried out at National Center of Public Laboratories (NCPHL).Two $\mathrm{ml}$ of whole blood was collected in an EDTA tube for detection of HBVDNA while three $\mathrm{ml}$ was put in a plain tube for detection of Hepatitis B surface Ag (HBsAg) and liver enzymes AST and ALT. Demographic data were collected at the time of sample collection using a predesigned questionnaire.

Detection of Hepatitis $B$ surface antigen and antiHBc-IgM: HBsAg and anti-HBc IgM in patient serum were detected by ELISA method (Closed systemAbbott diagnostic). Samples that were positive for $\mathrm{HBsAg}$ and anti-HBc $\operatorname{IgM}$ negative were enrolled in this study.

Estimation of the serum levels of alanine and aspartate transaminase: Serum level of AST and ALT were measured using Enzyme kinetics method (kit -AGAPPE, spectrophotometer-Bayer Diagnostic RA-50Clinical chemistry-Ireland).

Determination of HBV - DNA by conventional PCR: a. Virus DNA Extraction and PCR amplification DNA of HBV was extracted using AccuPrep ${ }^{\circledR}$ Genomic DNA Extraction Kit (Bioneer, Korea) in accordance with the manufacturer's instructions. Extracted DNA was stored at $-20^{\circ} \mathrm{C}$ for later analysis. HBV-DNA was then amplified using 1508 bp of $\mathrm{P}$ through $\mathrm{S}$ genes using universal primers, (FA2F) sense 
primer was reported by (S1-2) antisense primer that was described by Naito et al, $2001^{34}$, shown in Table 1 using AccuPower® ProFi Taq PCR PreMix (bioneer Korea-Bio meter system, Germany $)^{34}$. The PCR program was run for one cycle as: initial denaturation at $94^{\circ} \mathrm{C}$ for 5 minutes, 35 cycles consisted of denaturation at $94^{\circ} \mathrm{C}$ for $30 \mathrm{sec}$, annealing at $57^{\circ} \mathrm{C}$ for one minute followed by extension at $72^{\circ} \mathrm{C}$ for 1.5 minutes. The final extension was $72{ }^{\circ} \mathrm{C}$ for 5 minutes.

Table 1: Universal Primer sequences used for $\mathrm{HBV}$ detection.

\begin{tabular}{crr}
\hline Name primer & Sequences & Position \\
\hline FA2F & 5`-GCGTCGCAGAAGATCTCAAT -3` & 2413-2432 \\
S1-2-R & 5-CGA ACC ACT GAA CAA ATG GC-3 & 685-704 \\
\hline
\end{tabular}

\section{b. Determination of $\mathrm{HBV}$ genotypes}

Genotyping system was based on nested PCR, using type specific primers for determination of six genotypes A through $\mathrm{F}$ of $\mathrm{HBV}$, using (AccuPower® Gold Multiplex PCR PreMix from Bioneer-Bio metar system, Germany). The nested PCR primers were designed based on the conserved nature of the nucleotide sequences in regions of the $\mathrm{P}$ through $\mathrm{S}$ genes. The genotypes can be determined according to differences in the sizes of amplified DNA, in respective of the six HBV genotypes Table 2. Two nested PCRs were performed in different mixtures for each sample: mix 1 (sit 1) applied for identification of genotypes A,
B, C with B2 sense universal primer and mix 2 (set 2) for genotypes D, E, F by B2R antisense universal primer. The nested PCR mixture made of $1 \mu \mathrm{L}$ aliquot of the first-round of PCR product in each of mix A and mix $B, 1 \mu l$ of each type specific primers (10 p mole) and $11 \mu \mathrm{ldd} \mathrm{H}_{2} \mathrm{O}$. The nested PCRs were amplified for 40 cycles with the following parameters: initial denaturation at $95^{\circ} \mathrm{C}$ for 10 minutes, 20 cycles of amplification at $94^{\circ} \mathrm{C}$ for 20 seconds, $58^{\circ} \mathrm{C}$ for 20 seconds, and $72^{\circ} \mathrm{C}$ for 30 seconds, and 20 cycles of $94^{\circ} \mathrm{C}$ for 20 seconds, $60^{\circ} \mathrm{C}$ for 20 seconds, and $72^{\circ} \mathrm{C}$ for 30 seconds. Amplicon products were electrophoresed on a $3 \%$ agarose gel, stained with ethidium bromide, and evaluated under UV light.

Table 2: Primer sequences used for HBV genotyping by nested PCR.

\begin{tabular}{|c|c|c|c|}
\hline Name primer & & Sequences & Position \\
\hline B2- sense & \multirow{4}{*}{$\begin{array}{c}\text { Set } 1 \\
(\mathrm{~A}, \mathrm{~B}, \mathrm{C})\end{array}$} & 5-GGC TCM AGT TCM GGA ACA GT-3 & $67-86$ \\
\hline A- antisense & & 5 -CTC GCG GAG ATT GAC GAG ATG T-3 & $113-134$ \\
\hline B- antisense & & 5'-CAG GTT GGT GAG TGA CTG GAG A-3` & $324-345$ \\
\hline C- antisense & & 5-GGT CCT AGG AAT CCT GAT GTT G-3` & $165-186$ \\
\hline D- sense & \multirow{4}{*}{$\begin{array}{c}\text { Set } 2 \\
(\mathrm{D}, \mathrm{E}, \mathrm{F})\end{array}$} & 5`GCC AAC AAG GTA GGA GCT-3` & $2979-2996$ \\
\hline E- sense & & 5 -CAC CAG AAA TCC AGA TTG GGA CCA-3 & $2955-2978$ \\
\hline F- sense & & 5-GYT ACG GTC CAG GGT TAC CA-3` & $3032-3051$ \\
\hline $\mathrm{B} 2 \mathrm{R}$ & & 5'-GGA GGC GGA TYT GCT GGC AA-3` & 3078-3097 \\
\hline
\end{tabular}

\section{RESULTS}

The mean age of HBV patients was $32.64 \pm 7.67$ years. Most of CHB patients $(24,48 \%)$ were at age group 2030 years old and only two (4\%) CHB patients at age group $>50$ years old. Majority of $\mathrm{CHB}$ patients were males $(38,76 \%)$ table (3). Distribution of $\mathrm{HBV}$ genotypes among study population is shown in table (4). Out of 50 patients, 30 patients $(60 \%)$ had mixed genotypes, followed equally by genotype $\mathrm{B}$ and genotype $\mathrm{D}(8,16 \%)$ and finally genotype $\mathrm{A}(4,8 \%)$. Genotypes C, E, and F were not found alone but found in combinations with other genotypes. Mixed genotypes included $\mathrm{A}+\mathrm{B}+\mathrm{C}+\mathrm{D}+\mathrm{E} \quad(20,66.67 \%)$ followed by $\mathrm{A}+\mathrm{B}+\mathrm{C}+\mathrm{D}+\mathrm{E}+\mathrm{F}$ genotypes $(6,20 \%)$ and finally genotypes $\mathrm{A}+\mathrm{B}+\mathrm{C}+\mathrm{D} \quad(4,13.33 \%$.). The association between HBV genotypes and certain risk factors is shown in table (5). The association between the blood transfusion and HBV genotypes was found to be statistically significant $(\chi 2=13.06 ; p=0.005)$. However, the surgical and dental procedures had no association with HBV genotypes in study groups $(\chi 2=$ 3.96; $p=0.27 ; \chi 2=1.39 ; p=0.71$, respectively).

\section{DISCUSSION}

HBV infection is a significant health problem in Yemen with intermediate to high endemicity of hepatitis $\mathrm{B}^{35}$. HBV genotypes have attracted more attention as they may influence disease progression and outcome of HBV-associated chronic liver disease, in addition to patient's response to antiviral treatments 36 . Therefore, this study focuses on evaluating the prevalence of the HBV genotype in Yemen. This molecular genotyping of hepatitis B virus was the first of its kind in Yemen using a polymerase chain reaction (PCR)-based method, and no data on hepatitis B virus genotypes and mutations in hepatitis patients have been previously reported. However, there was a previous study in genotyping of $\mathrm{HCV}$ conducted in Yemen ${ }^{37}$. The small sample size may be an important limitation of this study, but we can justify this for two reasons: first by calculating the sample size using previous data from Yemen and the region, this calculation confirmed that 50 samples could be sufficient to achieve significant results similar to those that might be obtained of a larger sample size; Secondly, the cost of genetic testing was high for Sana'a University, which approved funds to conduct only 50 genetic tests. 
Table 3: Characteristics of chronic hepatitis B patients.

\begin{tabular}{lccc}
\hline & & No. & \% \\
\hline \multirow{2}{*}{ Gender } & Males & 38 & 76 \\
& Females & 12 & 24 \\
& Total & 50 & 100 \\
\hline \multirow{4}{*}{ Age mean } & SD $=32.64 \pm 7.67$ \\
\multirow{2}{*}{ Age group (year) } & $20-30$ & 24 & 48 \\
& $31-40$ & 21 & 42 \\
& $41-50$ & 3 & 6 \\
& $>50$ & 2 & 4 \\
\multirow{2}{*}{ AST } & Total & 50 & 100 \\
\hline \multirow{2}{*}{ ALA } & Normal & 20 & 40 \\
& High & 30 & 60 \\
\hline \multirow{2}{*}{} & Normal & 20 & 40 \\
& High & 30 & 60 \\
\hline
\end{tabular}

The mean age of the studied group is $32.64 \pm 7.67$ years, which means that the registered patients were born before the implementation of the national program for neonatal hepatitis $\mathrm{B}$ vaccination in Yemen. The majority of $\mathrm{CHB}$ patients were predominantly men (38, $76 \%)$ versus women $(12,24 \%)$. The tendency of hepatitis $\mathrm{B}$ infection to be more common in males than females may be because males are exposed to risk factors more frequently than females. Other studies from Yemen ${ }^{7-10}$, Saudi Arabia ${ }^{38}$, Bahrain $^{20}$, Rwanda ${ }^{39}$ and Pakistan ${ }^{40}$ reported that hepatitis $\mathrm{B}$ infection is more prevalent among males than females. The current study revealed that the majority of Yemeni patients with $\mathrm{CHB}$ are infected with multiple HBV genotypes. $\mathrm{CHB}$ patients with mixed infection had four (A/B/C/D) to six $(\mathrm{A} / \mathrm{B} / \mathrm{C} / \mathrm{D} / \mathrm{E} / \mathrm{F})$ different $\mathrm{HBV}$ genotypes which might indicate co-infection or superinfection with different genotypes. The most common mixed genotypes were $\mathrm{A}+\mathrm{B}+\mathrm{C}+\mathrm{D}+\mathrm{E}$ while the least common mixed genotypes were $\mathrm{A}+\mathrm{B}+\mathrm{C}+\mathrm{D}+\mathrm{E}+\mathrm{F}$. Genotypes $\mathrm{B}$, $\mathrm{D}$ and $\mathrm{A}$ were found to be mono-infection among $\mathrm{CHB}$ patients while Genotypes C, E, and F were only found in combinations with other genotypes. This result was similar to that described by Rashid and Saleh ${ }^{41}$, who found all Iraqi patients in their study had mixed infections ${ }^{42}$.

Table 4: Distribution of HBV genotypes in CHB* patients.

\begin{tabular}{lcc}
\hline Genotype & Frequency & \% \\
\hline A & 4 & 8 \\
B & 8 & 16 \\
D & 8 & 16 \\
Mix & 30 & 60 \\
\hline Total & $\mathbf{5 0}$ & $\mathbf{1 0 0}$ \\
\hline Mix & & \\
\hline A+B+C+D & 4 & 13.33 \\
A+B+C+D+E & 20 & 66.67 \\
A+B+C+D+E+F & 6 & 20 \\
\hline Total & $\mathbf{3 0}$ & $\mathbf{1 0 0}$ \\
\hline
\end{tabular}

However, our result differs from that reported from different countries around the world which reported that many patients are affected mainly by one genotype $\mathrm{e}^{16,42-46}$. For example, a study from Saudi Arabia, the country bordering Yemen, found genotype $\mathrm{D}$ to be the most common genotype among Saudi patients with $\mathrm{CHB}^{47}$. It also differs from that reported in the UAE which reported that many Emirati patients with viral hepatitis are commonly infected with either genotype $\mathrm{D}$ or $\mathrm{A}^{48}$. Moreover, the Egyptian study revealed that all $\mathrm{CHB}$ patients had genotype $\mathrm{D}$ in which sub-D1 genotype was dominant ${ }^{49}$.

Table 5: Association between HBV genotypes and risk factors among CHB patients.

\begin{tabular}{|c|c|c|c|c|c|c|c|c|c|c|c|c|c|}
\hline \multirow{3}{*}{$\begin{array}{l}\text { Risk } \\
\text { factor }\end{array}$} & \multicolumn{9}{|c|}{ Type of genotypes } & \multirow{2}{*}{\multicolumn{2}{|c|}{ Total }} & \multirow{3}{*}{$\chi 2 *$} & \multirow{3}{*}{$P^{* *}$} \\
\hline & & \multicolumn{2}{|c|}{$\mathbf{A}$} & \multicolumn{2}{|c|}{$\mathbf{B}$} & \multicolumn{2}{|c|}{ D } & \multicolumn{2}{|c|}{ Mix } & & & & \\
\hline & & No & $\%$ & No & $\%$ & No & $\%$ & No & $\%$ & No & $\%$ & & \\
\hline Blood & Yes & 4 & 20 & 2 & 0 & 2 & 10 & 8 & 40 & 20 & 40 & 13.0 & 0.005 \\
\hline transfusion & No & 0 & 0 & 6 & 20 & 6 & 20 & 22 & 73.3 & 30 & 60 & 6 & \\
\hline & Total & 4 & 8 & 8 & 16 & 8 & 16 & 30 & 60 & 50 & 100 & & \\
\hline Surgical & Yes & 0 & 0 & 2 & 20 & 0 & 0 & 8 & 80 & 10 & 20 & 3.96 & 0.27 \\
\hline procedure & No & 4 & 10 & 6 & 15 & 8 & 20 & 22 & 55 & 40 & 80 & & \\
\hline & Total & 4 & 8 & 8 & 16 & 8 & 16 & 30 & 60 & 50 & 100 & & \\
\hline Dental & Yes & 0 & 0 & 0 & 0 & 0 & 0 & 2 & 100 & 2 & 4 & 1.39 & 0.71 \\
\hline procedure & No & 4 & 8.3 & 8 & 16.6 & 8 & 16.6 & 28 & 58.3 & 48 & 96 & & \\
\hline & Total & 4 & 8 & 8 & 16 & 8 & 16 & 30 & 60 & 50 & 100 & & \\
\hline
\end{tabular}


With regard to risk factors, blood transfusion was found to be significantly associated with transmission of HBV genotypes in which patients may be exposed to co-infection or super-infection by transfusion of contaminated blood. No surgical history or dental operation was found to be significantly associated with HBV genotypes infection. A blood transfusion may result in mixed infection in recipients if blood from donors who are carriers of hepatitis B virus are not tested or tested using low-sensitivity laboratory techniques ${ }^{8-10}$. Shortcoming of this study was the fairly small sample size. Only 50 patients were tested for HBV genotypes, which may not represent the accurate picture of HBV genotypes among HBV patients.

\section{CONCLUSION}

In conclusion, this study demonstrates the general prevalence of hepatitis B virus genotypes among HBVinfected Yemeni hepatitis B patients who seek medical attention in a hospital. In mono-genotype HBV infection, genotype B and D were the most prevalent genotypes. In $\mathrm{HBV}$ mixed genotype infection, the $\mathrm{A} / \mathrm{B} / \mathrm{C} / \mathrm{D} / \mathrm{E}$ genotype was the most prevalent in the study area. Clinical trials and treatment regimens should be hypothesized individually based on genotype to effectively manage chronic $\mathrm{HBV}$ infection in the future. To this end, a prospective national population study of HBV genotype distribution and clinical outcomes is recommended. Testing blood donors with highly sensitive tests is also essential to avoid crossinfection and severe infection with hepatitis B virus.

\section{AUTHORS' CONTRIBUTIONS}

EMA, AMA, AMO, HAA, AA and SSB contributed equally to the design, implementation, statistical analysis and manuscript drafting. All authors read and approved the final manuscript.

\section{ACKNOWLEDGEMENTS}

Authors are grateful to all patients who participated in this study.

\section{CONFLICT OF INTEREST}

There is no conflict of interest with this research.

\section{REFERENCES}

1. Shen T, Yan XM. Hepatitis B virus genetic mutations and evolution in liver diseases. World J Gastroenterol 2014; 20(18):5435-5441. https://doi.org/10.3748/wjg.v20.i18.5435

2. CDC. Hepatitis B. accessed on 1 January 2019.

3. WHO. Hepatitis B. 18 July 2019

4. Al-kadassy AM, Al-Ashiry AFS, Al-Shamahy HA. Seroepidemiological study of hepatitis B, C, HIV and Treponema pallidum among blood donors in Hodeida cityYemen. Universal J Pharm Res 2019; 4(2):1-6. https://doi.org/10.22270/ujpr.v4i2.256

5. AL-Marrani WHM and Al-Shamahy HA. Prevalence of $\mathrm{HBV}$ and $\mathrm{HCV}$; and their associated risk factors among public health center cleaners at selected public health centers in Sana'a city-Yemen. Universal J Pharm Res 2018; 3(5):1-8. https://doi.org/10.22270/ujpr.v3i5.204

6. Murad EA, Babiker SM, Gasim GI, Rayis DI, Adam I. Epidemiology of hepatitis $\mathrm{B}$ and hepatitis $\mathrm{C}$ virus infections in pregnant women in Sana'a, Yemen. BMC Pregnancy Childbirth 2013; 13: 127.

7. Al-Shamahy HA, Ajrah MA, Al-Madhaji AG, et al. Prevalence and potential risk factors of hepatitis B virus in a sample of children in two selected areas in Yemen. Universal J Pharm Res 2019; 4(3): 1-5. https://doi.org/10.22270/ujpr.v4i3.269

8. AL-Shamahy HA. Prevalence of Hepatitis B surface antigen and Risk factors of HBV infection in samples of healthy mothers and their infants in Sana'a, Yemen. Ann Saudi Med 2000; 20: 464-467. https://doi.org/10.5144/0256-4947.2000.464

9. Al-Shamahy HA, Rabbad IA, Al-Hababy A. Hepatitis B virus serum markers among pregnant women in Sana'a, Yemen. Ann Saudi Med 2003; 23:87-89. https://doi.org/10.5144/0256-4947.2003.87

10. Al-Shamahy HA, Hanash SH, Rabbad IA, Al-Madhaji NM. Hepatitis B vaccine coverage and the immune response in children under 10 years old in Sana'a Yemen. SQU Med J 2011; 11(1):77-82. PMID: 21509212

11. Amran OAA, Al-Shamahy HA, Al Hadad AM, Jaadan BM. Explosion of hepatitis $\mathrm{B}$ and $\mathrm{C}$ viruses among hemodialysis patients as a result of hemodialysis crisis in Yemen. Universal J Pharm Res 2019; 4(5):1-6. https://doi.org/10.22270/ujpr.v4i5.311

12. Kramvis A. Molecular characteristics and clinical relevance of African genotypes and sub-genotypes of hepatitis B virus. South Afr Med J1 2018; S.1: 17-21. https://doi.org/10.7196/SAMJ.2018.v108i8b.13495

13. Yin Y, He K, Wu B, et al. A systematic genotype and subgenotype re-ranking of hepatitis $\mathrm{B}$ virus under a novel classification standard. Heliyon 2019; 5(10): e02556. https://doi.org/10.1016/j.heliyon.2019.e02556

14. Janahi EM, Ilyas Z, Al-Othman S, Darwish A, et al.. Hepatitis B virus genotypes in the Kingdom of Bahrain: Prevalence, gender distribution and impact on hepatic biomarkers. Medicina 2019; 55, 622. https://doi.org/10.3390/medicina55100622

15. Vachon A, Osiowy C. Novel biomarkers of Hepatitis B virus and their use in chronic Hepatitis B patient management. Viruses 2021; 13, 951. https://doi.org/10.3390/v13060951

16. Mahmood M, Anwar MA, Khanum A, Zaman N, Raza A. Distribution and clinical significance of hepatitis $B$ virus genotypes in Pakistan. BMC Gastroenterol 2016; 16: 104. https://doi.org/10.1186/s12876-016-0513-5

17. Datta S. An overview of molecular epidemiology of hepatitis B virus (HBV) in India. Virol J 2008; 5: 156. https://doi.org/10.1186/1743-422X-5-156

18. Awan Z, Idrees M, Amin I, Butt S, Afzal S. Pattern and molecular epidemiology of hepatitis B virus genotypes circulating in Pakistan. Infect Genet Evol 2010; 10: 12421246. https://doi.org/10.1016/j.meegid.2010.08.006

19. Patel NH, Meier-Stephenson V, Genetu M, et al. Prevalence and genetic variability of occult hepatitis B virus in a human immunodeficiency virus positive patient cohort in Gondar, Ethiopia. PLoS ONE 2020; 15(11): e0242577. https://doi.org/10.1371/journal.pone.0242577

20. Janahi EM, Ilyas Z, Al-Othman S, et al. Hepatitis B virus genotypes in the Kingdom of Bahrain: prevalence, gender distribution and impact on hepatic biomarkers. Medicina 2019; 55: 622. https://doi.org/10.3390/medicina55100622

21. Tran TT, Trinh TN, Abe K. New complex recombinant genotype of hepatitis B virus identified in Vietnam. J Virol 2008; 82: 5657-5663. https://doi.org/10.1128/JVI.02556-07

22. Phung TB, Alestig E, Nguyen TL, Hannoun C, Lindh M. Genotype X/C recombinant (putative genotype I) of 
hepatitis B virus is rare in Hanoi, Vietnam-Genotypes B4 and C1 predominate. J Med Virol 2010; 82: 1327-1333. https://doi.org/10.1002/jmv.21775

23. Mahmood M. Hebatitis B Virus Genotypes in Pakistan. Adv Res Gastroentero Hepatol 2017; 5(5): 00104-00107. https://doi.org/10.19080/ARGH.2017.05.555673

24. Kramvis A. Genotypes and genetic variability of Hepatitis B Virus. Intervirol 2014; 57:141-150. https://doi.org/10.1159/000360947

25. Sanchez-Tapias JM, Costa J, Mas A, Bruguera M, Rodes $\mathrm{J}$. Influence of hepatitis B virus genotype on the long-term outcome of chronic hepatitis B in western patients. Gastroenterol 2002; 123: 1848-56. https://doi.org/10.1053/gast.2002.37041

26. Ito K, Yotsuyanagi H, Sugiyama M, Yatsuhashi $\mathrm{H}$, et al. Geographic distribution and characteristics of genotype A hepatitis $\mathrm{B}$ virus infection in acute and chronic hepatitis B patients in Japan. J Gastroenterol Hepatol 2016; 31(1): 180-9. https://doi.org/10.1111/jgh.13030

27. Chan HL, Hui AY, Wong ML, Tse AM, Hung LC, Wong VW, Sung JJ. Genotype C hepatitis B virus infection is associated with an increased risk of hepatocellular carcinoma. Gut 2004; 53(10): 1494-1498. https://doi.org/10.1136/gut.2003.033324

28. Chan HL, Wong ML, Hui AY, et al. Hepatitis B virus genotype $\mathrm{C}$ is associated with more severe liver fibrosis than genotype B. Clinical gastroenterology and hepatology 2009; 7: 1361-1366 https://doi.org/10.1016/j.cgh.2009.08.004

29. Sumi H, Yokosuka O, Seki N, et al.. Influence of hepatitis $B$ virus genotypes on the progression of chronic type $B$ liver disease. Hepatol 2003; 37(1): 19-26. https://doi.org/10.1053/jhep.2003.50036

30. Erhardt A, Blondin D, Hauck K, Sagir A, Kohnle T, et al. Response to interferon alfa is hepatitis B virus genotype dependent: genotype A is more sensitive to interferon than genotype D. Gut 2005; 54: 1009-13. https://doi.org/10.1136/gut.2004.060327

31. Lin CL, Kao JH. Hepatitis B virus genotypes and variants. Cold Spring Harb Perspect Med 2015; 2015 (5):a021436. https://doi.org/10.1101/cshperspect.a021436

32. Al-Nabehi BA, Al-Shamahy H, Saeed WS, et al. Seromolecular epidemiology and risk factors of viral hepatitis in Urban Yemen. Int J Virol 2015; 11(3):133-138. https://doi.org/10.3923/ijv.2015.133.138

33. Ministry of Public Health and Population (Yemen) | Facts Sheet.

34. Naito H, Hayashi S, Abe K. Rapid and specific genotyping system for Hepatitis B virus corresponding to six major genotypes by PCR using type-specific primers. J Clin Microbiol 2001; 39(1):362-364. https://doi.org/10.1128/JCM.39.1.362-364.2001

35. Al-Kasem MAA, Abbas MAl-K, Ebtihal MM, Alshamahy HA. Hepatitis B virus among dental clinic workers and the risk factors contributing for its infection. On J Dent \& Oral Health. 1(2): 2018. https://doi.org/10.33552/OJDOH.2018.01.000509

36. Tufon KA, Meriki, HD, Anon DN, Mbunkah HN, Nkuo AG. Diversity, viraemic and aminotransferases levels in chronic infected hepatitis B patients from Cameroon. BMC Res Notes 2016; 9(117): 1-7. https://doi.org/10.1186/s13104-016-1916-7

37. Al-Shamahy HA, Sultan Ahmed Abdu S. Genotyping of Hepatitis C Virus (HCV) in Infected Patients from Yemen. Eur J Basic Med Sci 2013; 3(4): 78-82.PMID: 18626432

38. Abdullah SM. Prevalence of Hepatitis B and C virus infection and their co-relation with hematological and hepatic parameters in subjects undergoing Premarital Screening in the Jazan Region, Kingdom of Saudi Arabia. Pak J Med Sci 2018; 34(2): 316-321. https://doi.org/10.12669/pjms.342.14278

39. Makuza JD, Rwema JOT, Ntihabose CK, et al. Prevalence of hepatitis B surface antigen (HBsAg) positivity and its associated factors in Rwanda. BMC Infect Dis 2019; 19(1): 381. https://doi.org/10.1186/s12879-019-4013-4

40. Khan F, Shams S, Qureshi ID, et al. Hepatitis B virus infection among different sex and age groups in Pakistani Punjab. Virol J 2011; 8: 225.

https://doi.org/10.1186/1743-422X-8-225

41. Rashid PMA, Salih GF. Identification and genotyping of hepatitis B virus by PCR assay using genotype specific primers. European Sci J 2014; 10(9).

42. Matsuura K, Tanaka Y, Hige S, et al. Distribution of hepatitis B virus genotypes among patients with chronic infection in Japan shifting toward an increase of genotype A. J Clin Microbiol 2009; 47(5): 1476-83. https://doi.org/10.1128/JCM.02081-08

43. Świderska M, Pawłowska M, Mazur W, et al. Distribution of HBV genotypes in Poland. Clin Exp Hepatol 2015; 1(1):1-4. https://doi.org/10.5114/ceh.2015.51372

44. Hundie GB, Raj VS, Michael DG, et al. Molecular epidemiology and genetic diversity of hepatitis B virus in Ethiopia. J Med Virol 2016; 88(6): 1035-1043. https://doi.org/10.1002/jmv.24437. Epub 2015 Dec 22

45. Rahman MA, Hakim F, Ahmed M, Ahsan CR, Nessa J, Yasmin M. Prevalence of genotypes and subtypes of hepatitis B viruses in Bangladeshi population. Springerplus 2016; 5: 278.

https://doi.org/10.1186/s40064-016-1840-2. eCollection 2016

46. Lampe E, Mello FCA, do Espírito-Santo MP, et al. Nationwide overview of the distribution of hepatitis B virus genotypes in Brazil: a 1000-sample multicentre study. J Gen Virol 2017; 98(6):1389-1398 https://doi.org/10.1099/jgv.0.000789

47. Al-Qahtani AA, Pourkarim MR, Trovão NS, et al. Molecular epidemiology, phylogenetic analysis and genotype distribution of hepatitis B virus in Saudi Arabia: Predominance of genotype D1. Infect Genet Evol 2020;77:104051. https://doi.org/10.1016/j.meegid.2019.104051

48. Alfaresi MS. Molecular epidemiological study of Hepatitis $B$ virus in the United Arab Emirates based on the analysis of Pre-S gene. J Med Microb Diagn 2012; 1:4

49. El-Mowafy M, Elgaml A, El-Mesery M, Elegezy M. Molecular analysis of Hepatitis B virus sub-genotypes and incidence of preS1/preS2 region mutations in $\mathrm{HBV}$ infected Egyptian patients from Mansoura. J Med Virol 2017; 89(9):1559-1566.

https://doi.org/10.1002/jmv.24828. Epub 2017 May 23 